This article was downloaded by: [72.229.38.143]

On: 14 November 2013, At: 07:13

Publisher: Taylor \& Francis

Informa Ltd Registered in England and Wales Registered Number: 1072954 Registered office: Mortimer House, 37-41 Mortimer Street, London W1T 3JH, UK

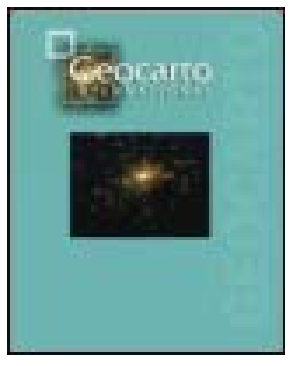

\title{
Geocarto International
}

Publication details, including instructions for authors and subscription information:

http://www.tandfonline.com/loi/tgei20

\section{Improving decision-making activities for meningitis and malaria}

Pietro Ceccato ${ }^{a}$, Sylwia Trzaskab ${ }^{b}$, Carlos Pérez García-Pando ${ }^{a c}$, Olga Kalashnikova ${ }^{d}$, John del Corral $^{a}$, Rémi Cousin ${ }^{a}, M$. Benno Blumenthal $^{\mathrm{a}}$, Michael Bell ${ }^{\mathrm{a}}$, Stephen J. Connor ${ }^{\mathrm{e}}$ \& Madeleine C. Thomson $^{\text {af }}$

a International Research Institute for Climate and Society, The Earth Institute, Columbia University, Palisades, NY, USA.

${ }^{\mathrm{b}}$ Center for International Earth Science Information Network (CIESIN), The Earth Institute, Columbia University, Palisades, NY, USA.

c Department of Applied Physics and Applied Mathematics, NASA Goddard Institute for Space Studies, Columbia University, New York, NY, USA.

${ }^{d}$ NASA Jet Propulsion Laboratory, Pasadena, CA, USA.

e School of Environmental Sciences, University of Liverpool, Liverpool, UK.

${ }^{f}$ Department of Environmental Health Sciences, Mailman School of Public Health, Columbia University, New York, NY, USA. Accepted author version posted online: 06 Aug 2013.Published online: 13 Nov 2013.

To cite this article: Pietro Ceccato, Sylwia Trzaska, Carlos Pérez García-Pando, Olga Kalashnikova, John del Corral, Rémi Cousin, M. Benno Blumenthal, Michael Bell, Stephen J. Connor \& Madeleine C. Thomson , Geocarto International (2013): Improving decision-making activities for meningitis and malaria, Geocarto International, DOI: 10.1080/10106049.2013.827749

To link to this article: http://dx.doi.org/10.1080/10106049.2013.827749

\section{PLEASE SCROLL DOWN FOR ARTICLE}

Taylor \& Francis makes every effort to ensure the accuracy of all the information (the "Content") contained in the publications on our platform. However, Taylor \& Francis, our agents, and our licensors make no representations or warranties whatsoever as to the accuracy, completeness, or suitability for any purpose of the Content. Any opinions and views expressed in this publication are the opinions and views of the authors, 
and are not the views of or endorsed by Taylor \& Francis. The accuracy of the Content should not be relied upon and should be independently verified with primary sources of information. Taylor and Francis shall not be liable for any losses, actions, claims, proceedings, demands, costs, expenses, damages, and other liabilities whatsoever or howsoever caused arising directly or indirectly in connection with, in relation to or arising out of the use of the Content.

This article may be used for research, teaching, and private study purposes. Any substantial or systematic reproduction, redistribution, reselling, loan, sub-licensing, systematic supply, or distribution in any form to anyone is expressly forbidden. Terms \& Conditions of access and use can be found at http://www.tandfonline.com/page/termsand-conditions 
Geocarto International, 2013

http://dx.doi.org/10.1080/10106049.2013.827749

Taylor \& Francis Taylor \& Francis Group

\title{
Improving decision-making activities for meningitis and malaria
}

\author{
Pietro Ceccato ${ }^{\mathrm{a} *}$, Sylwia Trzaskab ${ }^{\mathrm{b}}$, Carlos Pérez García-Pando ${ }^{\mathrm{a}, \mathrm{c}}$, Olga Kalashnikova ${ }^{\mathrm{d}}$, \\ John del Corral ${ }^{\mathrm{a}}$, Rémi Cousin ${ }^{\mathrm{a}}$, M. Benno Blumenthal ${ }^{\mathrm{a}}$, Michael Bell ${ }^{\mathrm{a}}$, \\ Stephen J. Connor ${ }^{\mathrm{e}}$ and Madeleine C. Thomson ${ }^{\mathrm{a}, \mathrm{f}}$ \\ ${ }^{a}$ International Research Institute for Climate and Society, The Earth Institute, Columbia \\ University, Palisades, NY, USA; ${ }^{b}$ Center for International Earth Science Information Network \\ (CIESIN), The Earth Institute, Columbia University, Palisades, NY, USA; ${ }^{\circ}$ Department of Applied \\ Physics and Applied Mathematics, NASA Goddard Institute for Space Studies, Columbia \\ University, New York, NY, USA; ${ }^{d}$ NASA Jet Propulsion Laboratory, Pasadena, CA, USA; ${ }^{e}$ School \\ of Environmental Sciences, University of Liverpool, Liverpool, UK, ${ }^{f}$ Department of Environmental \\ Health Sciences, Mailman School of Public Health, Columbia University, New York, NY, USA
}

(Received 31 May 2012; final version received 18 July 2013)

\begin{abstract}
Public health professionals are increasingly concerned about the potential impact that climate variability and change can have on infectious disease. The International Research Institute for Climate and Society (IRI) is developing new products to increase the public health community's capacity to understand, use and demand the appropriate climate data and climate information to mitigate the public health impacts of climate on infectious disease, in particular meningitis and malaria. In this paper, we present the new and improved products that have been developed for: (i) estimating dust aerosol for forecasting risks of meningitis and (ii) for monitoring temperature and rainfall and integrating them into a vectorial capacity model for forecasting risks of malaria epidemics. We also present how the products have been integrated into a knowledge system (IRI Data Library Map Room, SERVIR) to support the use of climate and environmental information in climate-sensitive health decision-making.
\end{abstract}

Keywords: meningitis; malaria; remote sensing; dust; air temperature; vectorial capacity model

\section{Introduction}

Many infectious diseases are climate sensitive (Kelly-Hope \& Thomson 2008), and although climate is only one of the many drivers of infectious diseases, public health policy-makers and practitioners are increasingly concerned about the potential impact of climate change on the health of populations. New opportunities exist for better management of climate-related health risks. These are made available through advances in climate science (predictability of El Niño events, for example, and climate change predictions), satellite-based environmental monitoring technologies (such as the MODIS satellite sensor, which provides global, free and routine information on the state of the environment), rapidly advancing communication technologies that impact on data and knowledge sharing, and a new global focus on effective management. The International

*Corresponding author. Email: pceccato@iri.columbia.edu

(C) 2013 Taylor \& Francis 
Research Institute for Climate and Society (IRI) is a Pan-American Health Organization/ World Health Organization Collaborating Centre for Early Warning Systems for malaria and other Climate Sensitive Diseases. In recent years, we have focused our research efforts on the creation of new climate and environmental products that may serve decision-maker needs. Our efforts have concentrated on meningococcal meningitis, which occurs during the winter dusty and dry season in Sahelian Africa, and malaria, a vectorborne disease that follows the rainy season throughout much of Africa.

\section{Meningococcal meningitis}

Meningitis is an inflammation of the protective membranes covering the brain and spinal cord. While there are many causes of meningitis, the epidemic form of the disease is caused by the bacteria Neissera meningitidis. Human carriers transmit the bacteria through respiratory droplets or throat secretions. Under certain circumstances, the bacteria become pathogenic, invading the naso-pharageal epithelial cells and entering the blood stream. Meningococcal meningitis is one of the most feared diseases in Africa because of its rapid onset, high fatality rates and induced long-term disabilities. Epidemic outbreaks pose a serious threat to populations and place a severe burden on the public health system and socio-economic development. The highest disease rates are concentrated in sub-Saharan Africa, in an area called the 'Meningitis Belt' (Figure 1). The Meningitis Belt coincides with the Sahel, a semi-arid region in

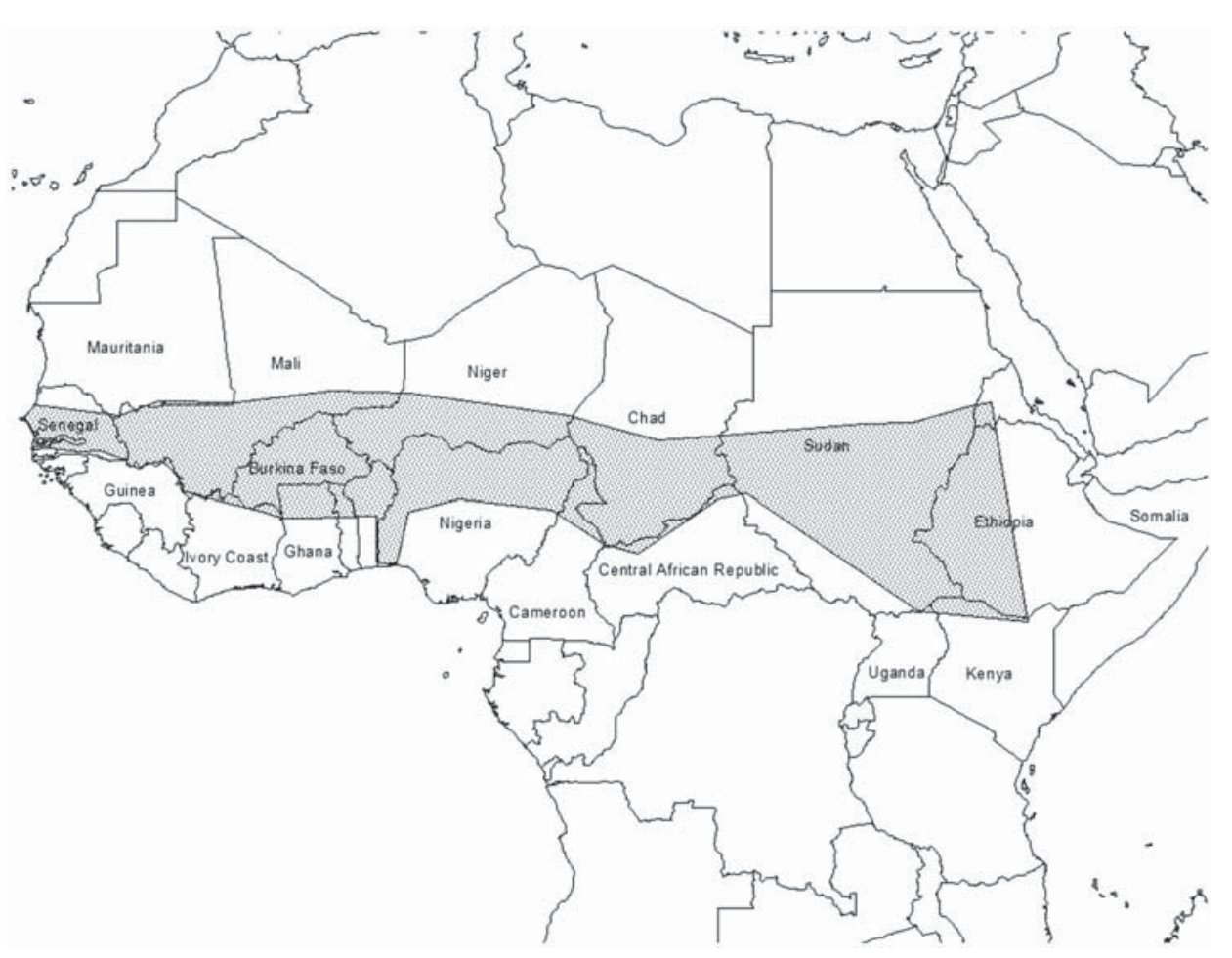

Figure 1. The meningitis belt in sub-Saharan Africa. Boundaries redrawn from the Centres for Disease Control and Prevention and World Health Organization map (2011). 
sub-Saharan Africa with relatively uniform physical features that receives between 300 and $1100 \mathrm{~mm}$ of annual rainfall in the single summer rainy season.

Meningitis occurs during the dry season, which is characterized by high daily temperatures and the Harmattan, a ground level stream of dry and dusty desert air, which is part of the African continental trade wind system that sweeps far southward from a consistent north-east direction between the end of November and the middle of March. Environmental conditions have been long highlighted as driving factors of meningitis (Lapeyssonnie 1963; Cheesbrough et al. 1995; Molesworth et al. 2003), and human/social factors have also been identified. High population density, high poverty levels, household crowding, smoking and indoor smoke have been suggested as possible risk factors (Hart \& Cuevas 1997; Stuart et al. 1988; Williams et al. 2004). Knowledge of environmental conditions has been successfully used to predict spatial characteristics of meningitis risk (Molesworth et al. 2003), and attempts to predict meningitis timing and severity have been made for Mali, Burkina Faso and Niger (Sultan \& Janicot 2003; Thomson et al. 2006; Yaka et al. 2008). Dukić et al. (2012) showed that high temperatures coupled with low humidity and dust may favour the conversion of carriage to disease as the meningococcal bacteria in the nose and the throat are better able to cross the mucosal membranes into the blood stream. The challenges facing decision-makers interested in forecasting meningitis outbreaks using climatic and environmental drivers are investigated within the 'Meningitis Risk Information Technologies' (MERIT) project led by the World Health Organization, the World Meteorological Organization, Group on Earth Observations, International Federation of Red Cross and Red Crescent Societies, Health and Climate Foundation, Agencia Estatal de Meteorologia and the IRI (http://merit.hc-foundation.org) (Thomson et al. 2013).

\section{Malaria}

Given its impact on populations and the gravity of its pathology, malaria remains one of the most significant infectious diseases. Malaria is a leading cause of morbidity and mortality in the developing world, especially sub-Saharan Africa, where the transmission rates are highest and where it is considered to be a major impediment to economic development (Sachs \& Malaney 2002). Malaria is a preventable and curable disease whose causal agent, a Plasmodium spp. parasite, is transmitted throughout the globe by a select number of Anopheles vector mosquitoes. It is essentially an environmental disease since the vectors require specific habitats with surface water for reproduction and sufficient humidity for adult mosquito survival. Additionally, the development rates of both the vector and parasite populations are influenced by temperature. In sub-Saharan Africa, the pattern of malaria transmission varies markedly from region to region, depending on climate and biogeography, and broad ecological categories have been widely used to describe variations in the observed epidemiological patterns (Mouchet et al. 1993). Towards either end of this spectrum of variation, malaria transmission is classified as stable or unstable. A region prone to stable malaria is characterized by high transmission levels with little inter-annual variation. In these areas, collective immunity to the disease in the population is high, and epidemics are unlikely. A region prone to unstable malaria is characterised by transmission levels that vary from year to year. In these areas, collective immunity is low and disease, when it does occur, affects all age groups and is often severe. Unstable malaria areas are essentially found in warm, semi-arid zones, tropical mountainous 
areas and regions where previous levels of control are beginning to fail. It has long been known that in these areas, any change in temperature, relative humidity or rainfall can have a major impact on malaria transmission, possibly leading to epidemics (Macdonald 1953; Ceccato et al. 2005).

In this paper, we present new and improved products that have been developed based on remotely sensed Earth observation data for monitoring (i) dust, for forecasting risks of meningitis and (ii) air temperature used in a vectorial capacity model for forecasting risks of malaria epidemics. We also present how the products have been integrated into knowledge systems (IRI Data Library Map Room, NASA SERVIR, and Google Earth) to support the use of climate and environmental information in climatesensitive health decision-making (Del Corral et al. 2012).

\section{New earth observation products}

\section{Monitoring and modelling dust aerosol for meningitis study}

Atmospheric aerosols have a strong impact on climate and environment by, for example, altering the global energy balance, affecting ozone chemistry, and impacting oceanic and terrestrial biochemical cycles. They also directly affect a number of human activities by reducing visibility, thus disturbing ground and air transportation, or directly threatening human health by causing acute respiratory and eye infections, pneumonia, bronchitis, cardiovascular disease and potentially meningococcal meningitis. The latter is particularly severe in the so-called 'Meningitis Belt' where the attack rates are many times higher than elsewhere in the world. The high frequency of epidemics there has been associated with environmental conditions including high concentrations of aerosols (Thomson et al. 2006; Cuevas et al. 2007). The region lies within the Sahara-Sahel 'Dust Corridor', extending from Chad to Mauritania, along which winter Harmattan winds blow huge amounts of mineral dust, mainly from north-east to south-west. To the south of this region, intensive burning of agricultural waste occurs in the dry season, and aerosol particles - mainly black carbon and organic carbon - are transported into the region by the warm and moist southerly winds. Studies have been severely limited by the use of horizontal visibility data or column-integrated measurements from satellites as proxies for exposure. The determination of surface aerosol concentrations is needed to establish a detailed assessment of human exposure levels, and to assess the limitations of proxy historical data to perform such assessments. The Sun photometers of the AERONET network have been documenting aerosol optical depth (AOD - integrated extinction coefficient over a vertical column of unit cross section) over the globe, but only few measurement points exist in the Sahara and the Sahel (16 stations - Figure 2).

Although the data span the period 1995-2009, different stations have been reporting for different periods of time (Figure 3), making any attempt to generate a spatially extended view of aerosol properties and any analysis of their impacts on human health difficult.

Existing satellite remote-sensing data do not provide the necessary information since they may only partially capture surface conditions and they have a number of limitations. Quantifying human exposure combining observations and models is crucial to understand and quantify atmospheric aerosol health impacts in sub-Saharan Africa. In order to compensate for the paucity in the spatial and temporal coverage of the AERONET data, we investigated the use of (i) the Multi-angle Imaging 


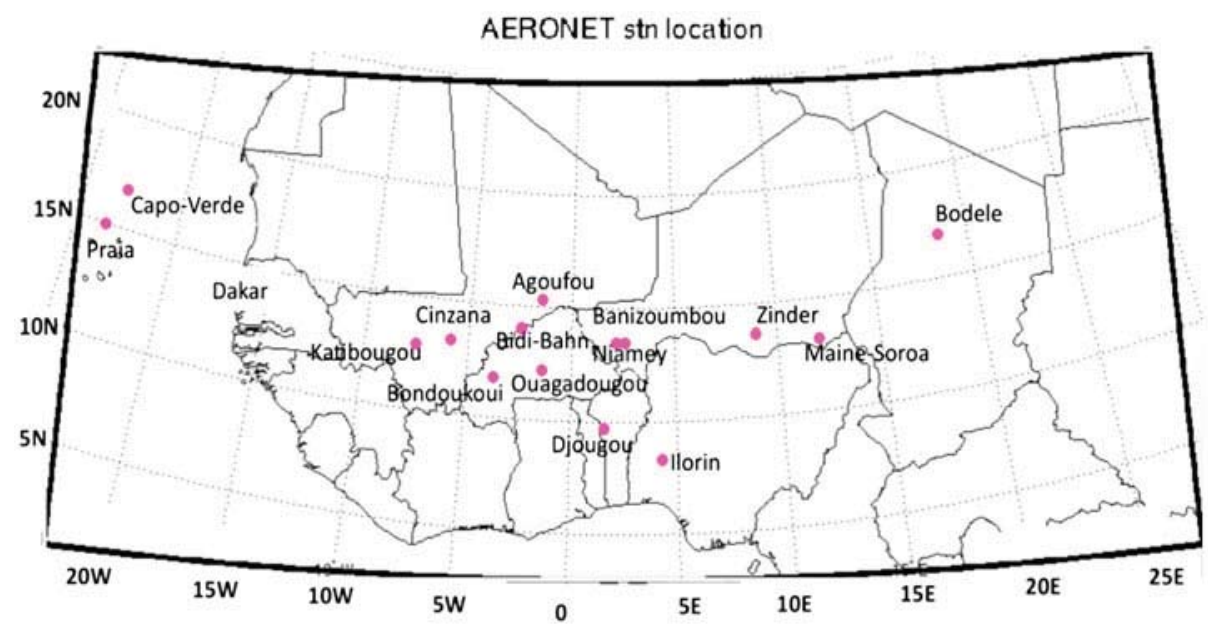

Figure 2. Locations of AERONET AOD measurements in the Sahara and the Sahel.

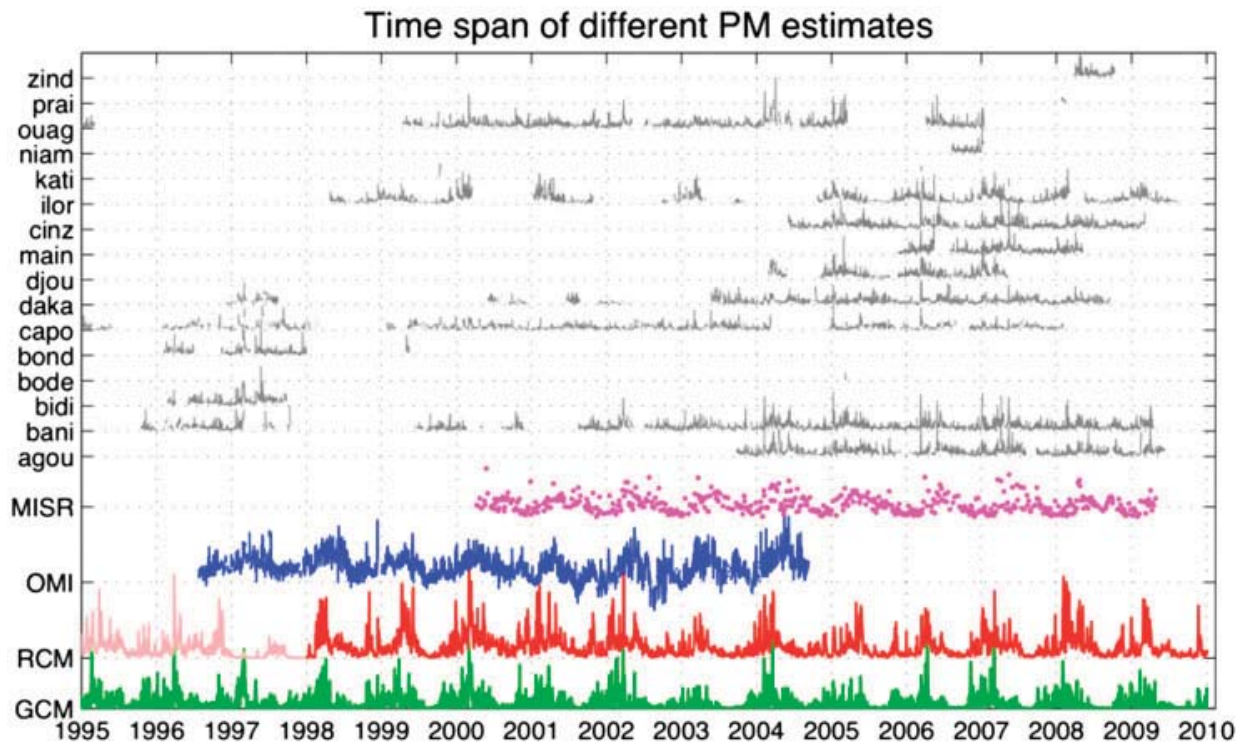

Figure 3. Time-series of available measurements at 16 AERONET stations (top black plots, referenced by four first letters of location). MISR (pink dots), OMI (blue), NMMB/BSC-dust (red) and GISS ModelE (green).

SpectroRadiometer (MISR) and (ii) the Ozone Monitoring Instrument (OMI) Aerosol Index (AI), and recently developed dust models to provide more insight into the horizontal and vertical structure of aerosol properties. However, these products needed to be validated against observations. We compared the AOD from the AERONET stations with: 
AOD derived from:

(a) MISR satellite sensor (Kalashnikova et al. 2005) available daily at $0.25^{\circ}$ spatial resolution.

(b) GISS Global ModelE (GCM) (Miller et al. 2006) available every $6 \mathrm{~h}$ at $2.5^{\circ}$ spatial resolution.

(c) Regional model NMMB/BSC-Dust (RCM) (Perez et al. 2011) available every $3 \mathrm{~h}$ at $1.25^{\circ}$ spatial resolution.

AI derived from OMI (McPeters et al. 1998) available daily at $1.0^{\circ}$ spatial resolution.

The correlations between daily values of different variables at different locations, using all available data points, are summarized in Figure 4. Best fit between AERONET AOD and gridded data was obtained for MISR data with correlation coefficients for all the locations above 0.6 with a significant correlation median of 0.82 . Correlation values between OMI vs. AERONET and RCM vs. AEORNET showed a larger spatial variability than MISR vs. AERONET and correlation median values were lower (respectively 0.64 and 0.56 ). The GCM vs. AERONET shows high spatial variability of correlations and poor skill in general with all variables extracted from AERONET, MISR and OMI (correlation median below 0.4 ). RCM is consistently well correlated (above 0.4 ) with

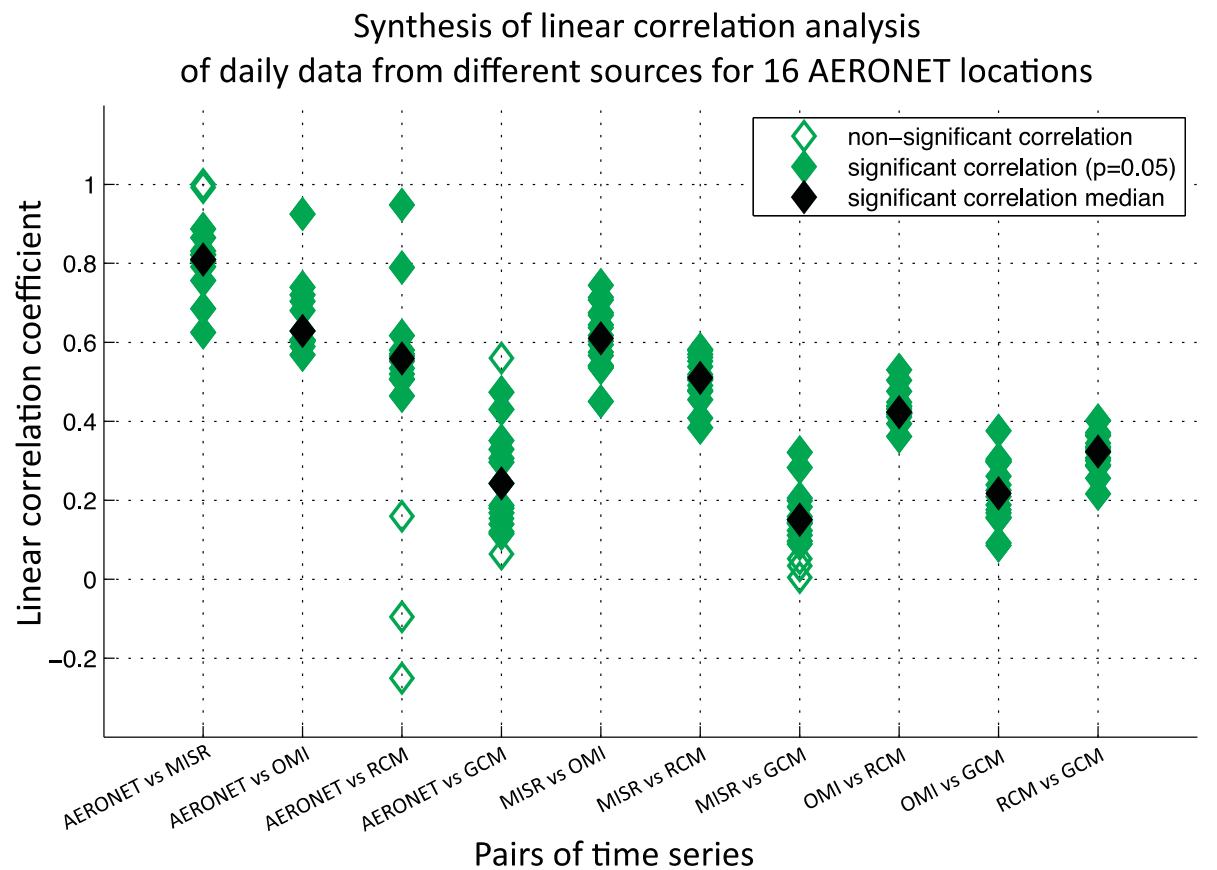

Figure 4. Linear correlation coefficients between time series of daily data from different products at the 16 AERONET locations. Correlation coefficients for each aeronet location and each pair of variables have been reported: filled green dots for correlation coefficients significant at least $p=0.05$, unfilled dots for non-significant correlation coefficients (mainly due to small sample size for the given location); and black dots for median of significant correlation coefficients. 
AERONET, MISR and GCM, and thus could be used as a surrogate for observations, as it has a longer time span and better spatial and temporal coverage, supplementing satellite data.

Although the MISR products seem to provide a better point estimation of aerosols than the models (GCM and RCM), MISR products do not provide the high temporal and spatial coverage (daily values covering the entire region for an extended period) of dust events that is required to understand the risk of meningitis outbreaks. Good performance of the RCM gives us hope that the combination of RCM and MISR data will give a good representation of mineral dust in the region. While the GCM may not perform as well in this 'point' validation, it is expected that it will capture well other aspects such as interannual variability and larger scale events, not investigated in this study. Further investigations will assess how well MISR and the two models capture the seasonal cycle and inter-annual variability of dust, and how the dust products are related to the variability of meningitis epidemics.

\section{Monitoring air temperature, rainfall and vectorial capacity model for malaria}

A variety of satellite-derived rainfall estimation products have already been tested against ground observations (Dinku et al. 2007) and used for forecasting malaria outbreaks since 2005. Those products included the Malaria Early Warning System (MEWS), based on decadal rainfall estimates on a $0.1 \times 0.1^{\circ}$ lat/long grid produced by the Climate Prediction Centre (CPC)/Famine Early Warning System (Grover-Kopec et al. 2005), and a seasonal climatological suitability for malaria transmission product that describes where, when and for how long the combination of climatic conditions based on rainfall, temperature and relative humidity may be suitable for malaria transmission in endemic malaria on the African continent (Grover-Kopec et al. 2006).

\section{Air temperature products}

We have investigated new methods to estimate air temperature based on remotely sensed products. Particularly, we found that the Moderate Resolution Imaging Spectroradiometer (MODIS) sensor of Land Surface Temperature (LST) during the overnight pass was suitable to estimate minimum air temperature (Vancutsem et al. 2010). We then used the MODIS LST on board the AQUA satellite, whose overpass during the night is around 1:30 a.m. over Africa to map minimum air temperature on an eight-day composite at $1 \mathrm{~km}$ spatial resolution.

While minimum LST derived from MODIS night-time images provides a good surrogate for minimum air temperature (minimum $T_{\mathrm{a}}$ ), the retrieval of maximum air temperature (maximum $T_{\mathrm{a}}$ ) is less straightforward. Maximum $T_{\mathrm{a}}$ can differ from LST by as much as $20^{\circ} \mathrm{C}$ depending on the ecosystem and the time of the year (Vancutsem et al. 2010). We developed a new approach to estimate maximum $T_{\mathrm{a}}$ from minimum LST using a diurnal cycle climatology model based on surface weather observations of $T_{\mathrm{a}}$. It is important to note that diurnal cycle parameters (i.e. phase and amplitude) are site dependent. They are also sensitive to altitude and seasons. It is, therefore, important to determine the diurnal cycle locally to account for these temporal and spatial variations. In this context, a gridded data-set such as WORLDCLIM (Hijmans et al. 2005) can depict this variability in the space and time domain. Maximum $T_{\mathrm{a}}$ maps were created based on Aqua-MODIS LST night-time images and climatology data derived from WORLDCLIM. The WORLDCLIM database provides invaluable information on 
the monthly average of maximum and minimum $T_{\mathrm{a}}$ at $1 \mathrm{~km}$ spatial resolution. These inputs allowed us to characterize the diurnal cycle (amplitude and phase) and determine maximum $T_{\mathrm{a}}$ by extrapolating in time minimum $T_{\mathrm{a}}$ according to the determined diurnal cycle (Ceccato et al. 2010).

Resulting maps were validated with maximum $T_{\mathrm{a}}$ measured at $2 \mathrm{~m}$ at 28 stations located in Botswana (8 stations), Eritrea (4 stations), Ethiopia (8 stations) and Madagascar (8 stations) for the time period 2002-2008. In Eritrea, Botswana and Madagascar, the statistical results (Table 1) showed that the maximum $T_{\mathrm{a}}$ derived from AQUA MODIS LST and WORLDCLIM were close to the maximum $T_{\mathrm{a}}$ measured in-situ, with Mean Deviation (MD) close to 0 and RMSE at 2.08 (Madagascar) and 2.99 (Botswana) (Ceccato et al. 2010). The results for Ethiopia (MD -3.03 and RMSE 5.31) showed some discrepancies between maximum $T_{\mathrm{a}}$ and maximum $T_{\mathrm{a}}$ estimates and require further investigation.

We then developed the new maximum $T_{\mathrm{a}}$ product in the IRI Data Library based on the MODIS LST eight-day and the WORLDCLIM data (Figure 5). In addition to mapping the maximum $T_{\mathrm{a}}$, the Map Room allows users to compare the estimated maximum $T_{\mathrm{a}}$ time series at a selected location and a measurement of maximum $T_{\mathrm{a}}$ at the closest station available from the EVE data-set (Ropelewski et al. 1985) produced by the National Oceanic and Atmospheric Administration (NOAA), National Centres for Environmental Prediction and CPC (Figure 6).

\section{Vectorial capacity model product}

Vectorial capacity is a series of biological features that determine the ability of mosquitoes to transmit Plasmodium. It is defined as the daily rate at which future inoculations could arise from a currently infected case (Dye 1992), and it is generally used as a convenient way to express malaria transmission risk, or the receptivity of an area to malaria (Gilles 1993). For the purposes of this study, the Vectorial Capacity Model Product (VCAP) is adapted from Macdonald's model (Macdonald 1956) which is summarized in the formula for $Z_{0}$, the basic reproduction rate of malaria, as follows:

$$
Z_{0}=\frac{-\left(m a^{2} b\right) p^{n}}{r[\ln (p)]}=\left(\frac{b}{r}\right) V
$$

where $b$ represents the proportion of those anophelines with sporozoites in their salivary glands which are actually infective, $r$ is used to represent the daily rate each human

Table 1. Mean deviation (MD), median (MED), mean absolute error (MAE), standard deviation (SD), root-mean-square error (RMSE), skewness value (SKEW) and kurtosis value (KURT) of the difference between maximum $T_{\mathrm{a}}$ measured at stations $\left({ }^{\circ} \mathrm{C}\right)$ and maximum $T_{\mathrm{a}}$ estimated from MODIS/WORLDCLIM $\left({ }^{\circ} \mathrm{C}\right)$, by country, for all the weather stations.

\begin{tabular}{lrrrrrrr}
\hline Country & MD & MED & MAE & SD & RMSE & SKEW & KURT \\
\hline Ethiopia & -3.03 & -2.73 & 4.17 & 4.37 & 5.31 & -0.11 & 0.45 \\
Botswana & -0.93 & -0.85 & 2.40 & 2.84 & 2.99 & -0.03 & -0.31 \\
Madagascar & 0.20 & 0.18 & 1.62 & 2.07 & 2.08 & 0.04 & 0.28 \\
Eritrea & -0.33 & -0.25 & 1.71 & 2.08 & 2.11 & 0.01 & -0.11 \\
Total 4 countries & -1.16 & -0.75 & 2.63 & 3.40 & 3.60 & -0.72 & 1.61 \\
\hline
\end{tabular}




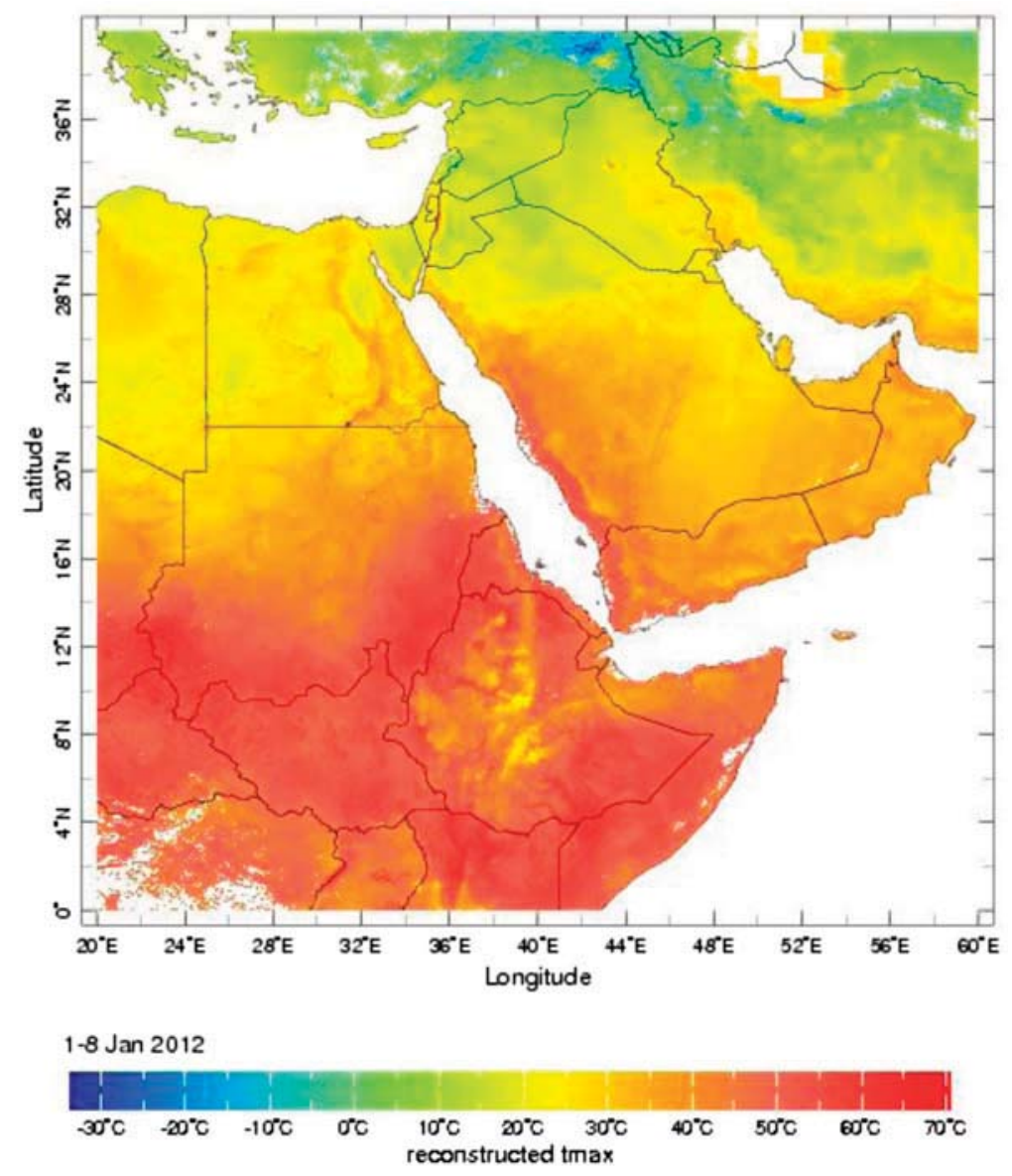

Figure 5. Every eight days, an average maximum $T_{\text {a }}$ map is constructed based on MODIS AQUA LST night and WORLDCLIM. The spatial resolution is $1 \mathrm{~km}$.

recovers from infection, $m$ is the number of vectors per host, $a$ is the human biting rate and $V$ is the 'Vectorial Capacity' of malaria, given by:

$$
V=\frac{-\left(m a^{2}\right) p^{n}}{\ln (p)}
$$

Parameter $p$ is the probability of a mosquito surviving through one whole day, and $n$ is the extrinsic incubation period of malaria parasites or 'the time taken for completion of the extrinsic cycle'.

Macdonald derived the basic reproduction rate $Z_{0}$ as an estimate of the average number of secondary cases arising in a very large population of completely susceptible humans at risk following the introduction of a single primary case. $Z_{0}=1$ was defined as the transmission threshold: for values of $Z_{0}$ above 1 , malaria cases will propagate while for values of $Z_{0}$ below 1 , the disease will recede (Smith et al. 2012).

Parameters $p, n, a$ and $m$ are influenced by temperature and rainfall. Temperature has an effect on both the vector and the parasite. For the vector, it affects the juvenile 


\section{Maximum Air Temperature Reconstructed - East Africa}

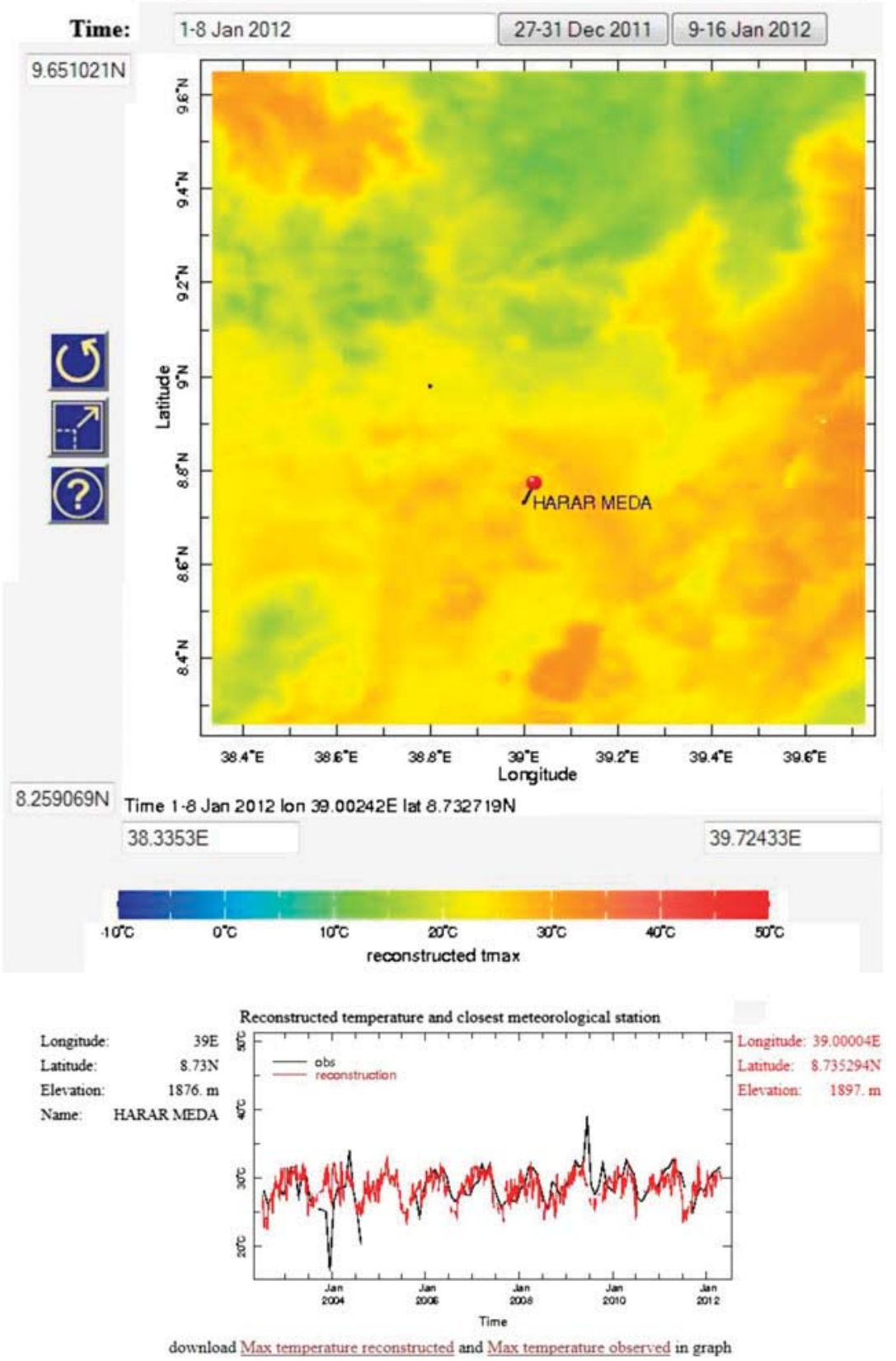

Figure 6. It is possible for the user to click on any point and automatically extract the time series of reconstructed maximum $T_{\mathrm{a}}$ and compare it with the closest station maximum $T_{\mathrm{a}}$. In this case, the reconstructed maximum $T_{\mathrm{a}}$ is compared with the maximum $T_{\mathrm{a}}$ measured at the station located at Harar Meda (Ethiopia). The red line time series represents the reconstructed maximum $T_{\mathrm{a}}$; the black line represents maximum $T_{\mathrm{a}}$ measurement at the station. 
development rates, the length of the gonotrophic cycle and survivorship of both juvenile (larval) and adult stages with an optimal temperature and upper and lower lethal boundaries. For the parasite, it effects the extrinsic incubation period (Lactin et al. 1995). Plasmodium falciparum (the dominant malaria parasite in Africa) requires a warmer minimum temperature than Plasmodium vivax. Temperature helps to account for the geographic limits of malaria transmission for this particular species in Africa (Bruce-Chwatt 1991). At $26^{\circ} \mathrm{C}$, the extrinsic incubation period of this malaria species is about $9-10$ days, whereas at $20-22^{\circ} \mathrm{C}$ it may take as long as $15-20$ days. In highland areas, where cold temperatures preclude vector and/or parasite development during part/ or all of the year, increased prevalence rates may be closely associated with higher than average minimum temperatures (Bouma et al. 1994).

The association between rainfall and malaria epidemics has been recognized for many decades (Christophers 1911), but, while increasing precipitation may increase vector populations in many circumstances by increasing available anopheles breeding sites, excessive rains may also have the opposite effect by flushing out small breeding sites, such as ditches or pools (Fox 1957) or by decreasing the temperature, which in regions of higher altitude can stop malaria transmission. Different malaria vectors use a variety of sites in which to lay their eggs (irrigation canals, tyre ruts, mangrove swamps, pools, etc.) as long as the water is not overly polluted, not too shaded, and, for most species, relatively still. In many semi-arid areas, these sites are only widely available with the onset of the seasonal rains unless dry-season irrigation is undertaken.

In Africa, the spatial distribution of weather stations is often limited and the dissemination of rainfall and temperature data is variable, therefore, limiting their use for real-time applications. Compensation for this paucity of information can be obtained by using satellite-based methods to monitor rainfall and air temperature. Based on previous validations of rainfall estimate products with rain gauge data (Dinku et al. 2008), we decided to use the satellite products derived from the Tropical Rainfall Measuring Mission (TRMM) sensor. The TRMM products (Huffman et al. 2007) are available on a 3-h basis from 1998 at $0.25^{\circ}$ spatial resolution and have been shown to provide a better spatial and temporal estimation of rainfall in Africa (Dinku et al. 2008) than most other rainfall estimate products.

To estimate minimum $T_{\mathrm{a}}$ and compute the VCAP model, we opted to use MODIS (on-board the AQUA satellite) night-time LST available on an eight-day basis at $1 \mathrm{~km}$ spatial resolution.

The USGS EROS Centre combined the temperature derived from MODIS night LST on an eight-day basis and the TRMM rainfall downscaled to $1 \mathrm{~km}$ spatial resolution to produce a $1 \mathrm{~km}$ VCAP map every eight-days specifically for the epidemic regions of sub-Saharan Africa. In Equation (3), the two raster images: MODIS night time LST and rainfall (TRMM) are integrated as follows:

$$
V=\frac{-\left(m a^{2}\right) p^{n}}{\ln (p)}
$$

where $m=10.0 \times$ TRMM,$a=0.7 /$ gonotrophic,$\quad$ gonotrophic $=[36.5 /(\mathrm{LST}+2.0-9.9)]$ $+0.5, \quad p=0.5^{(1.0 / \text { gonotrophic }))}, \quad n=111.0 /\{[2.0 \times(36.5 / \mathrm{LST}+2.0-9.9) /$ gonotrophic $]$ + LST -18.0$\}$ 
The coefficients used in the VCAP equation are at this stage not optimized to specific regions. The variability in VCAP is only driven by the LST and rainfall. This is a first attempt to spatially map risk of malaria transmission based on a vectorial capacity model (Ceccato et al. 2012).

The product (Figure 7) is made available on a regular basis (on an eight-day period) at $1 \mathrm{~km}$ spatial resolution for the period Jan 2004 to present on the FEWS NET Africa Data Portal web site: http://earlywarning.usgs.gov/fews/africa/web/imgbrowses2.php? extent=afvc and on the Data Library at http://iridl.ldeo.columbia.edu/maproom/.Health/. Regional/.Africa/.Malaria/. In the Data Library, it is possible for the user to extract a time series for any location and display recent VCAP values compared to previous years.

\section{Integration into knowledge systems}

\section{Data library description}

Relevant and accurate information is essential to making decisions about development and resource management. However, many decision-makers and researchers in

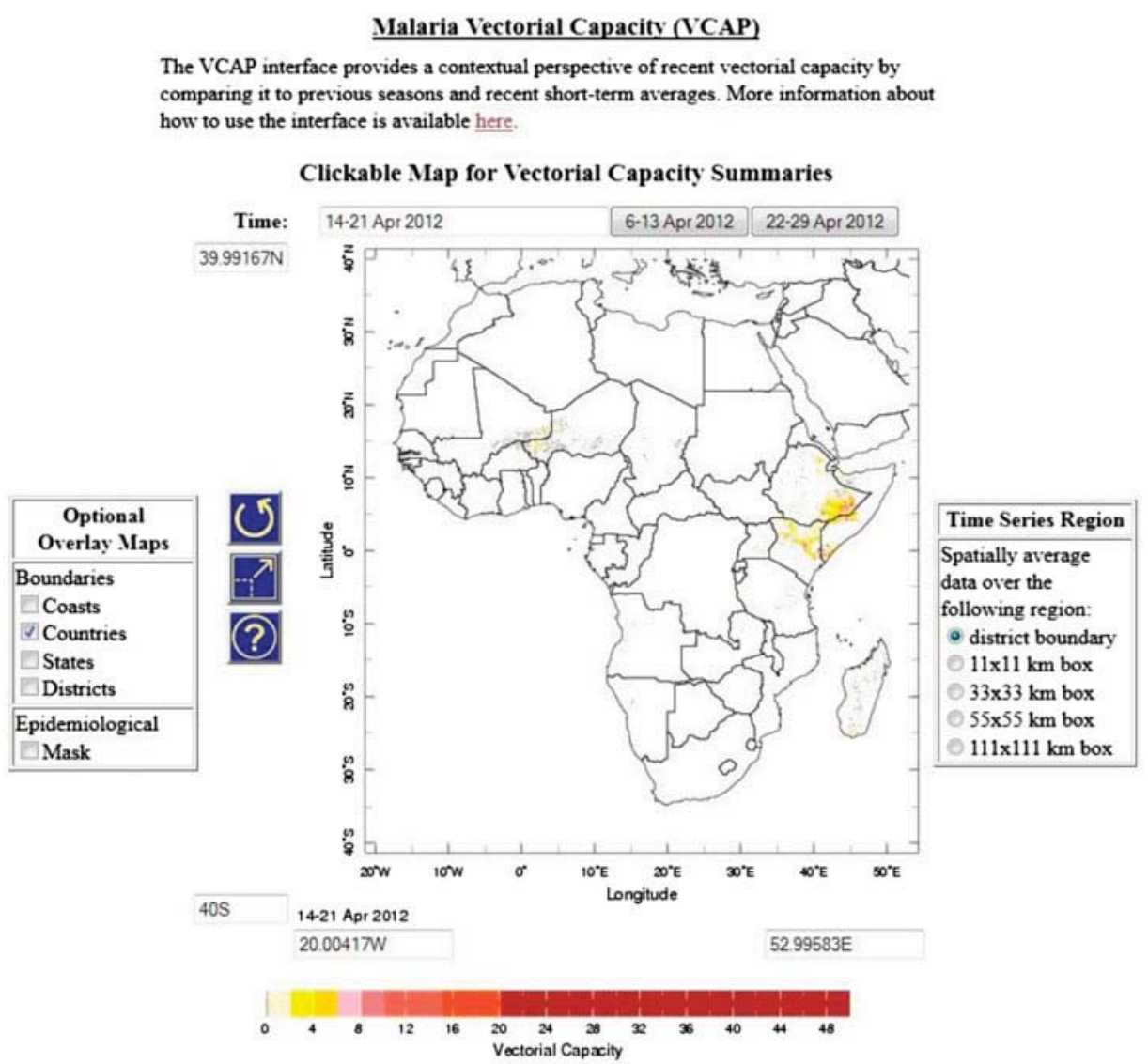

Figure 7. Malaria VCAP produced every eight days at $1 \mathrm{~km}$ spatial resolution. The user can click on any location and automatically extract time series of VCAP and compare it with the previous five years. 


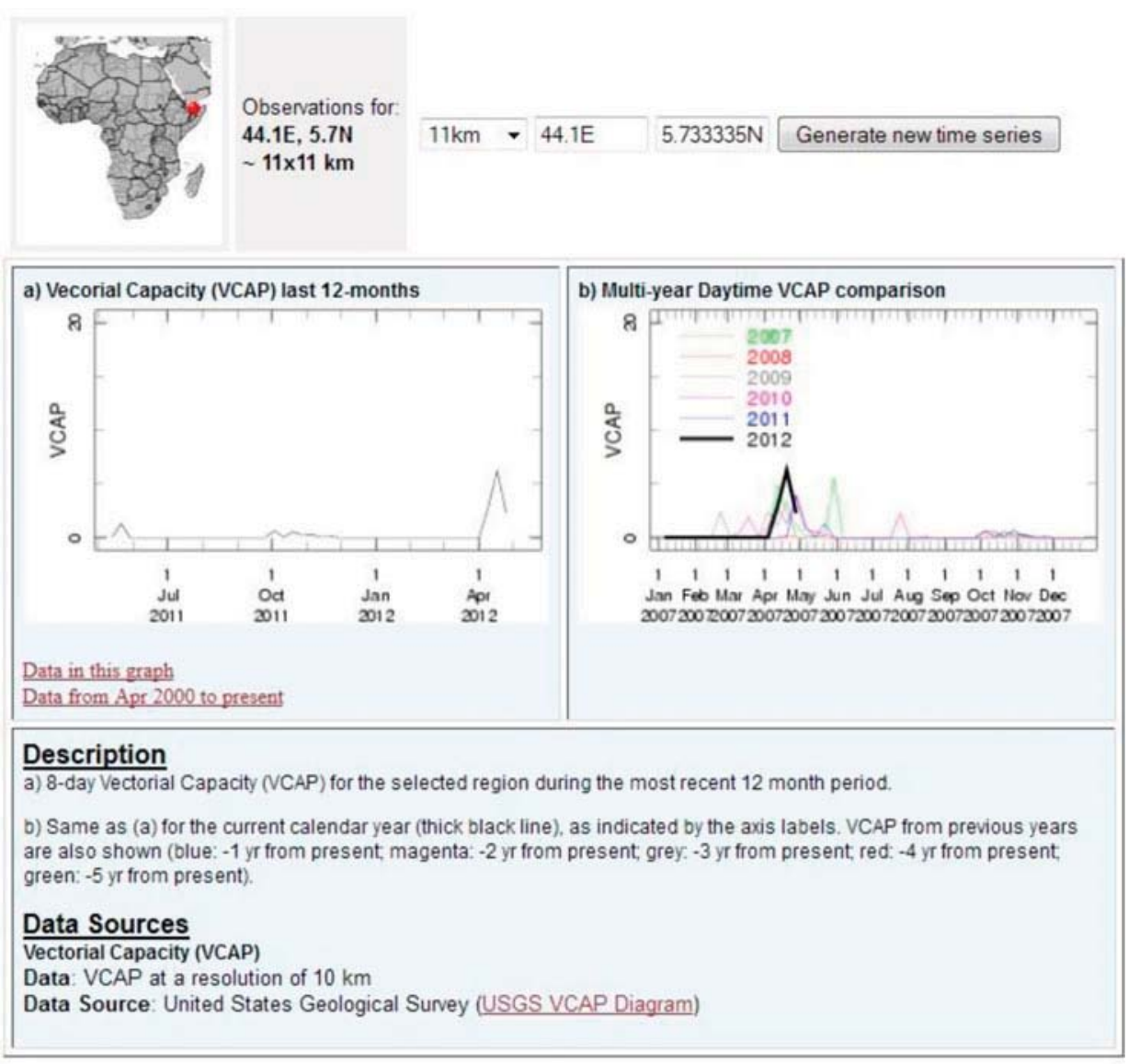

Figure 7. (Continued)

the developing world do not have access to comprehensive information about climate impacts, shocks and vulnerability. IRI's Data Library plays a crucial role by providing data to the scientific and technical communities that need it (Del Corral et al. 2012).

The Data Library is a free, web-accessible tool that allows users to manipulate, view and download earth science data-sets through a standard web browser. Initiated as an aid to climate scientists to do exploratory data analysis, the library has expanded to provide a platform for interdisciplinary researchers focused on topics related to climate impacts on society. The Data Library expands beyond the horizons of a conventional climate data repository to include derived analyses and satellite-measured environmental parameters. It contains observed and model-derived quantities influenced by climate, such as disease incidence, crop yields and population data. This expanded view of climate-related data makes interdisciplinary research easier to perform and facilitates the development of tools for effective use of climate information in a decision-making framework.

The Data Library includes an interactive data viewer that allows users to visualize multi-dimensional data-sets in a variety of ways, including time series graphs and two- 
dimensional maps. Users can customize images by selecting a number of different options including colour scales, specific map domains, and physical and geo-political boundaries. They can create animations and save images in any one of a number of user-specified formats. The data visualization capability allows decision-makers and researchers to share complex information quickly and easily.

An extensive array of statistical analysis tools is available to the library's users. They can compute analyses of varying complexity, from simple averages to advanced multivariate statistical analyses. A number of Data Library-based analyses have been compiled for quick reference in a section of the IRI web site called the Map Rooms (example Health Map Room http://iridl.ldeo.columbia.edu/maproom/.Health/.Regional/. Africa/.Malaria/). The majority of these maps and analyses are linked directly to the library and serve as another, user-friendly point to access it. Most of the contents found in the Map Rooms are analyses useful in climate diagnostics and monitoring efforts, but an increasing number is being created to serve climate-dependent sectors as well (Grover-Kopec et al. 2005, 2006).

\section{Meningitis map room}

The IRI Climate Data Library Meningitis Map Room has integrated the results from the regional dust model for the northern half of Africa (Perez et al. 2011). The model results include aerosol and meteorological variables on a 3-h time frequency. Dust monitoring products derived from the MISR (Kalashnikova et al. 2005) as well as the AERONET data are also made available. These additions are of benefit to the MERIT community, since it makes readily accessible gridded coverage of measurements in an area where there are sparsely distributed measuring stations (particularly for aerosols). The Data Library Meningitis Map Room, which is the portal to these datasets, is shown in Figure 8.

In addition to the environmental products, the Meningitis Map Room includes maps of population at risk developed in collaboration between the IRI and the Centre for International Earth Science Information Network.

\section{Malaria map room}

The IRI Climate Data Library Malaria Map Room has integrated the results from the minimum $T_{\mathrm{a}}$ and reconstructed maximum $T_{\mathrm{a}}$ data-sets and the Malaria Vectorial Capacity Model (Figure 9).

The current products available include:

(1) The MEWS

(2) Rainfall Estimate Differences (rainfall anomalies)

(3) Rainfall Estimate Percentages

(4) Vectorial Capacity Model

(5) MODIS Image Download Tools (to map water bodies)

(6) MODIS NDVI Analysis Tool

(7) MODIS EVI Analysis Tool

(8) Country-Average Weighted Anomaly Standardized Precipitation (WASP) Index

(9) Minimum Air Temperature 


\title{
Climate and Meningitis in Africa
}

\begin{abstract}
Epidemics of meningitis occur worldwide. The "meningitis belt" in the Sahel region of Africa, however, has the greatest incidence of the disease. Epidemics occur throughout the 'belt' in the dry season. They typically coincide with periods of very low humidity and dusty conditions and disappear with the onset of the rains, suggesting that these environmental factors may play an important role in the occurrence of the disease.
\end{abstract}

Megional dust model results from 1985-2006, including climate
variables, every 3 hours.

Figure 8. Climate and Meningitis in Africa Map Room available at: http://iridl.ldeo.columbia. edu/maproom/.Health/.Regional/.Africa/.Meningitis/.

(10) Maximum Air Temperature Reconstructed from MODIS night LST and WORLDCLIM

(11) Seasonal Climatic Suitability for Malaria Transmission

(12) MARA Distribution Model of Climatic Suitability for Malaria Transmission

(13) Malaria Atlas Project (MAP) Maps of Malaria Transmission and Endemicity

\section{Automatic integration into NASA SERVIR}

The IRI Map Room is currently delivered to web browsers as html pages containing tools that allow data-derived images to be viewed and manipulated. Metadata for these tools/pages are stored in an inferencing RDF/XML (Resource Description Framework) 


\section{Climate and Malaria in Africa}

Economic development has played an enormous role in shaping the current global distribution of malaria. Where malaria is not adequately controlled. however. its distribution and seasonality are closely related to seasonal characteristics of the climate. [Full Discussion]

The mapping products below therefore aim to illustrate models of climate suitability for seasonal endemic malaria, and recent climate conditions, such as rainfall anomalies, which may be associated with epidemic malaria in warm semi-arid regions of Africa. Additional models, such as that developed by the MARA Initiative, may be included in the future and we welcome the opportunity to work with others on the further development of these products.

References: Grover-Kopec E. K., Blumenthal M. B., Ceccato P., Dinku T., Omumbo J. A., Connor S. J. Web-based climate information resources for malaria control in Africa. Malaria Journal. 2006, 5:38.

Monitoring Tools for Epidemic Malaria
Malaria Early Warning System
estimates from the Climate Prediction Center. The interface allows
users to view recent rainfall estimates with a seasonal and recent
historical perspective. Time series analyses of rainfall data are
generated based on user-selected parameters.

Figure 9. Climate and Malaria in Africa Map Room available at: http://iridl.ldeo.columbia.edu/ maproom/.Health/.Regional/.Africa/.Malaria/.

triplestore database (sesame server (http://openrdf.org) with Owlim (http://www.ontotext.com/) and custom inferencing, and a web-accessible faceted search/browse interface is based on that information.

While the Data Library currently provides a Web Map Service (WMS) service point for any figure object generated within the data library, we are creating a cascading WMS server which wraps the individual layer service points as a single WMS server covering the IRI Map Room layers. This server uses the RDF triplestore information to generate the WMS GetCapabilities response that lists all the Map Room layers along with descriptive documentation and references to more complete documentation. It then relays subsequent GetMap requests to the appropriate underlying Data Library figure object WMS service point. Automatic integration into NASA SERVIR has been 


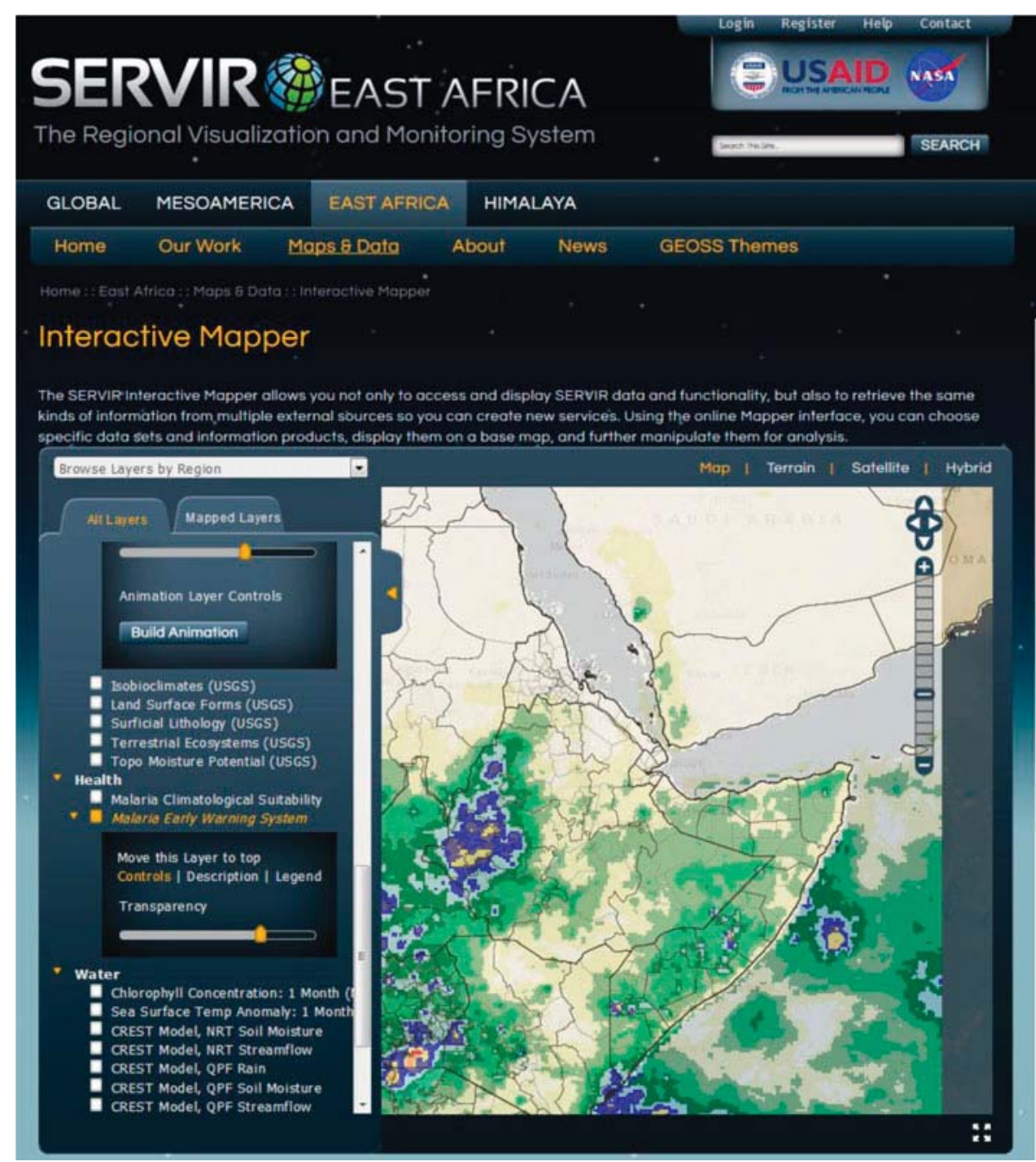

Figure 10. Integration of the MEWS form the IRI Data Library into the NASA SERVIR East Africa hub. The NASA SERVIR for East Africa is available at: http:/www.servirglobal.net/ EastAfrica.aspx.

developed for some of the health products (Figure 10) and current development is underway to deliver all the products available in the Meningitis and Malaria Map Room.

\section{Automatic integration into Google Earth}

The Data Library currently provides a Keyhole Markup Language (KML) access point for any figure object generated within the Data Library, allowing enhanced resolution as Google Earth zooms into a particular location, and display/control of time-dependent information (Figure 11).

We have enhanced the service by including clickable information in a number of the IRI Map Room pages. We also made the KML versions of the Map Room pages 


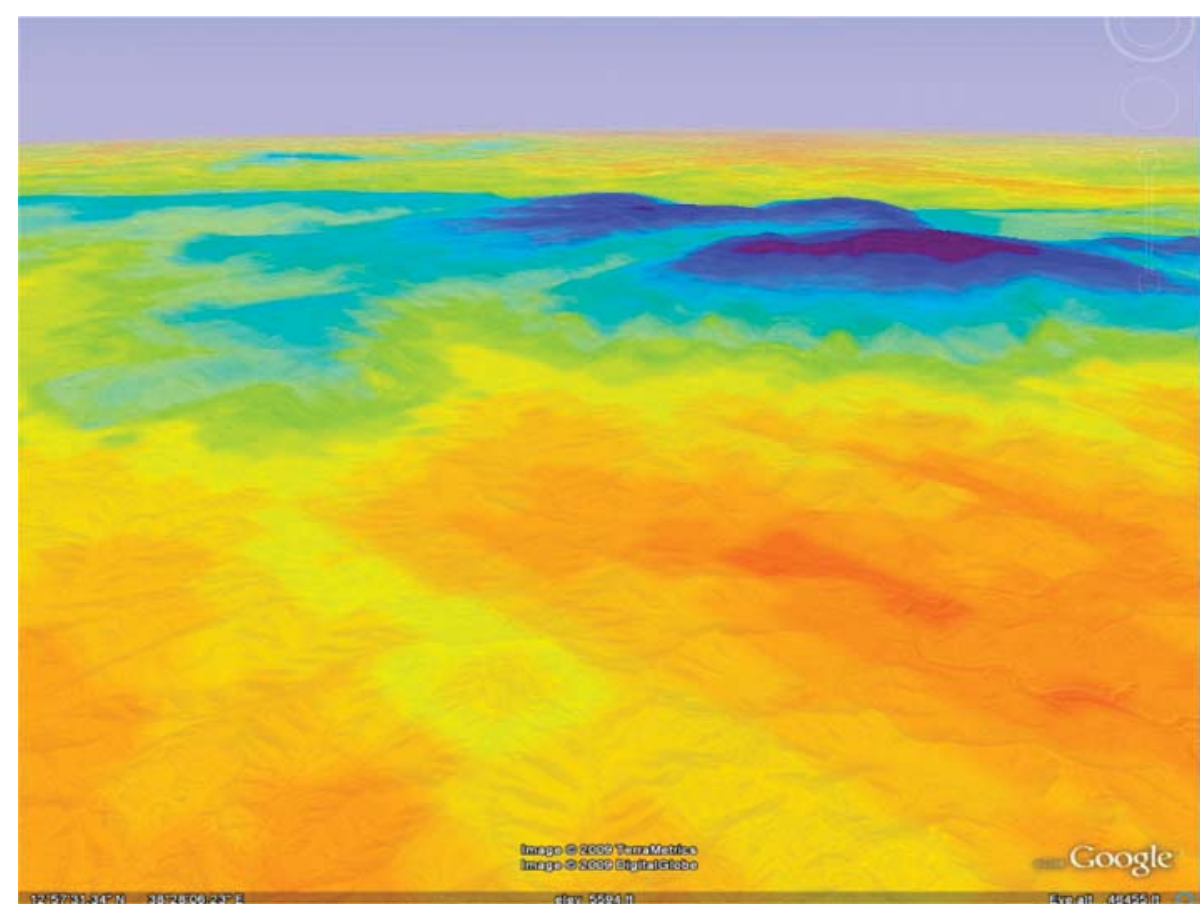

Figure 11. Integration of the AQUA MODIS night-time LST from the IRI Data Library Health Map Room into Google Earth. Blue colours represent temperature below $18^{\circ} \mathrm{C}$ (no malaria transmission). Location: Highlands in Ethiopia (Upper left corner:13.50 N - 38.0 E; Lower right corner: $12.5 \mathrm{~N}-38.8 \mathrm{E})$.

findable individually and as an IRI Map Room folder within Google Earth, the latter based on the RDF triplestore information.

\section{Conclusion}

The creation and analysis of new data/products derived from Earth Observations and models to monitor dust, air temperature and malaria vectorial capacity allow the user community composed by UN WHO and Ministries of Health in countries to better assess the risks of meningitis and malaria epidemics. Thanks to the development of the IRI Data Library Map Room on Health and its integration into NASA SERVIR and Google Earth, the access to the data is made easier for a non-remote-sensing specialist community, thus directly benefiting the decision process that the Ministries of Health and WHO have to take when predicting and preventing meningitis and malaria epidemics. These products are currently used by research communities (e.g. research groups in Africa within the World Health Organization Tropical Disease Research and WHO MERIT initiative) and Ministries of Health for assessing risks of malaria and meningitis epidemics.

\section{Acknowledgements}

The Data Library capacity to serve the needs of the health community has been supported with funding from a cooperative agreement (NA050AR4311004) from the National Oceanic and 
Atmospheric Administration (NOAA) and ROSES FEASIBILITY project (NNX11AF68G) from the National Aeronautics and Space Administration (NASA). The views expressed herein are those of the authors and do not necessarily reflect the views of NOAA or any of its sub-agencies. We also thank the two anonymous reviewers for their relevant comments.

\section{References}

Bouma MJ, Sorndorp HE, Van de Kaay HJ. 1994. Health and climate change. Lancet. 343:1440. Bruce-Chwatt LJ. 1991. Essential malariology, 2nd ed. London: Heinemann Medical Books Ltd.

Ceccato P, Connor SJ, Jeanne I, Thomson MC. 2005. Application of geographical information system and remote sensing technologies for assessing and monitoring malaria risk. Parassitologia. 47:81-96.

Ceccato P, Vancutsem C, Klaver R, Rowland J, Connor SJ. 2012. A vectorial capacity product to monitor changing malaria transmission potential in epidemic regions of Africa. J Trop Med. 2012:1-6, Article ID 595948, doi:10.1155/2012/595948.

Ceccato P, Vancutsem C, Temimi M. 2010. Monitoring air and land surface temperatures from remotely sensed data for climate-human health applications. International Geoscience and Remote Sensing Symposium (IGARSS), Honolulu (HI); p. 178-180.

Centers for Disease Control and Prevention, World Health Organization. 2011. Chapter 2: epidemiology of meningitis caused by Neissera meningitides, Streptococcus pneumonia and Haemorphilius influenza. Laboratory methods for the diagnosis of meningitis. 2nd ed. p. 8 (http://www.cdc.gov/meningitis/lab-manual/chpt02-epi.html)

Cheesbrough JS, Morse AP, Green SDR. 1995. Meningococcal meningitis and carriage in western Zaire: a hypoendemic zone related to climate? Epidemiol Infect. 114:75-92.

Christophers SR. 1911. Malaria in the Punjab. Scientific memoirs, by Officers of the Medical and Sanitary Departments of India. New Series. p. 46-197.

Cuevas LE, Jeanne I, Molesworth A, Bell MA, Savory EC, Connor SJ, Thomson MC. 2007. Risk mapping and early warning systems for the control of meningitis in Africa. Vaccine. 25S: A12-A17.

Del Corral J, Blumenthal MB, Mantilla G, Ceccato P, Connor SJ, Thomson MC. 2012. Climate information for public health: the role of the IRI climate data library in an integrated knowledge system. Geospatial Health. 6:S15-S24.

Dinku T, Ceccato P, Grover-Kopec EK, Lemma M, Connor SJ, Ropelewski CF. 2007. Validation of satellite rainfall products over East Africa's complex topography. Int J Remote Sens. 28:1503-1526.

Dinku T, Chidzambwa S, Ceccato P, Connor SJ, Ropelewski CF. 2008. Validation of high-resolution satellite rainfall products over complex terrain in Africa. Int J Remote Sens. 29:4097-4110.

Dukić V, Hayden M, Forgor AA, Hopson T, Akweongo P, Hodgson A, Monaghan A, Wiedinmyer C, Yoksas T, Thomson MC, et al. 2012. The role of weather in meningitis outbreaks in Navrongo, Ghana: a generalized additive modelling approach. J Agric Biol Environ Stat. $7: 442-460$.

Dye C. 1992. The analysis of parasite transmission by blood sucking insects. Annu Rev Entomol. 37:1-19.

Fox RM. 1957. Anopheles gambiae in relation to malaria and filariasis in coastal Liberia. Am J Trop Med Hyg. 6:598-620.

Gilles HM. 1993. Epidemiology of malaria. In: Gilles HM, Warrell DA, editors. Bruce-Chwatt's essential malariology, 3rd ed. London: Arnold; p. 124-163.

Grover-Kopec EK, Blumenthal MB, Ceccato P, Dinku T, Omumbo J, Connor SJ. 2006. Web-based climate information resources for malaria control in Africa. Malaria J. 5:1-9.

Grover-Kopec E, Kawano M, Klaver RW, Blumenthal B, Ceccato P, Connor SJ. 2005. An online operational rainfall monitoring resource for epidemic malaria early warning systems in Africa. Malaria J. 4:1-5.

Hart CA, Cuevas LE. 1997. Meningococcal disease in Africa. Ann Trop Med Parasitol. 91:777-785.

Hijmans R, Cameron S, Parra J, Jones P, Jarvis A. 2005. Very high resolution interpolated climate surfaces for global land areas. Int J Climatol. 25:1965-1978.

Huffman GJ, Adler RF, Bolvin DT, Gu G, Nelkin EJ, Bowman KP, Hong Y, Stocker EF, Wolff DB. 2007. The TRMM multi-satellite precipitation analysis: quasi-global, multi-year, combined-sensor precipitation estimates at fine scale. J Hydrometeorol. 8:38-55. 
Kalashnikova O, Kahn R, Sokolik IN, Li WH. 2005. Ability of multiangle remote sensing observations to identify and distinguish mineral dust types: optical models and retrievals of optically thick plumes. J Geophys Res D Atmos. 110:1-16.

Kelly-Hope LA, Thomson MC. 2008. Climate and infectious disease. In: Thomson MC, editor. Seasonal forecasts, climatic change, and human health. Wengen, Switzerland: Springer Science and Business Media B.V.; p. 31-70.

Lactin DJ, Holliday NJ, Johnson DL, Craigen R. 1995. Improved rate model of temperaturedependant development by arthropods. Environ Entomol. 24:68-75.

Lapeyssonnie L. 1963. Cerebrospinal meningitis in Africa. Bull WHO. 28:1-114.

Macdonald G. 1953. The analysis of malaria epidemics. Trop Dis Bull. 50:871-889.

Macdonald G. 1956. Theory of the eradication of malaria. Bull WHO. 15:369-387.

McPeters RD, Bhartia PK, Krueger AJ, Torres O, Herman JR. 1998. Earth probe total ozone mapping spectrometer (TOMS) data products user's guide. Greenbelt (MD): NASA Technical Publication.

Miller RL, Cakmur RV, Perlwitz J, Geogdzhayev IV, Ginoux P, Koch D, Kohfeld KE, Prigent C, Ruedy R, Schmidt GA, Tegen I. 2006. Mineral dust aerosols in the NASA Goddard Institute for Space Sciences ModelE atmospheric general circulation model. J Geophys Res. 111 :1-19. doi: 10.1029/2005JD005796.

Molesworth AM, Cuevas LE, Connor SJ, Thomson MC. 2003. Environmental risk and meningitis epidemics in Africa. Emerg Infect Dis. 9:1287-1293.

Mouchet J, Carnevale P, Coosemans M, Fontenille D, Ravaonjanahary C, Richard A, Robert V. 1993. Typologie du paludisme en Afrique. Cahier Santé. 3:220-238.

Perez C, Haustein K, Janjic Z, Jorba O, Huneeus N, Baldasano JM, Black T, Basart S, Nickovic S, Miller RL, et al. 2011. Atmospheric dust modeling from meso to global scales with the online NMMB/BSC-dust model: 1. Model description, annual simulations and evaluation. Atmos Chem Phys Discuss. 11:13001-13027.

Ropelewski CF, Janowiak JE, Halpert MS. 1985. The analysis and display of real time surface climate data. Mon Wea Rev. 113:1101-1106.

Sachs J, Malaney P. 2002. The economic and social burden of malaria. Nature. 457:680-685.

Smith DL, Battle KE, Hay SI, Barker CM, Scott TW, McKenzie FE. 2012. Ross, Macdonald, and a theory for the dynamics and control of mosquito-transmitted pathogens. PLoS Pathog. 8:13 e1002588.

Stuart JM, Cartwright KAV, Dawson JA, Rickard J, Noah ND. 1988. Risk factors for meningococcal disease: a case control study in south west England. J Public Health. 10:139-146.

Sultan B, Janicot S. 2003. The West African monsoon dynamics. Part II: the 'Preonset' and 'Onset' of the summer monsoon. J Clim. 16:3407-3427.

Thomson MC, Firth E, Jancloes M, Mihretie A, Onoda M, Nickovic S, Broutin H, Sow S, Perea W, Bertherat E, Hugonnet S. 2013. A climate and health partnership to inform the prevention and control of meningoccocal meningitis in sub-Saharan Africa: the MERIT initiative. In: Asrar GR, Hurrell JW, editors. Climate science for serving society: research, modeling and prediction priorities. Geneva (Switzerland): World Health Organization; p. 459-484.

Thomson MC, Molesworth A, Djingarey M, Yameogo K, Balenger F, Cuevas L. 2006. Potential for environmental models to predict meningitis epidemics in Africa. Tropical Med Int Health. 11:781-788.

Vancutsem C, Ceccato P, Dinku T, Connor SJ. 2010. Evaluation of MODIS land surface temperature data to estimate air temperature in different ecosystems over Africa. Remote Sens Environ. 114:449-465.

Williams CJ, Willocks LJ, Lake IR, Hunter PR. 2004. Geographic correlation between deprivation and risk of meningococcal disease: an ecological study. BMC Public Health. 4:1-11.

Yaka P, Sultan B, Broutin H, Janicot S, Philippon S, Fourquet N. 2008. Relationship between climate and year-to-year variability in meningitis outbreaks: a case study in Burkina Faso and Niger. Int J Health Geogr. 7:1-13. 